\title{
SOCIAL AND ECONOMIC CONSEQUENCES OF HISTORIC CALDERA UNREST AT THE TAUPO VOLCANO, NEW ZEALAND AND THE MANAGEMENT OF FUTURE EPISODES OF UNREST
}

\author{
David Johnston $^{1}$, Brad Scott ${ }^{1}$, Bruce Houghton ${ }^{1,2}$, Douglas Paton ${ }^{3}$, \\ David Dowrick ${ }^{4}$, Pilar Villamor ${ }^{4}$ and John Savage ${ }^{5}$
}

\begin{abstract}
In 1998, changes in a number of indicators (earthquakes and uplift) at two of New Zealand's active volcanic caldera systems (Okataina and Taupo) resulted in increased public, local and central government awareness and some concern about the potential significance of volcanic unrest at a caldera volcano. This paper summarises the episodes of unrest recorded at Taupo caldera since 1895. There have been four significant events (1895, 1922, 1963-64 and 1983) that have included earthquake activity and ground deformation. Caldera unrest is one of the most difficult situations the volcanological and emergency management communities will have to deal with. There is potential for adverse social and economic impacts to escalate unnecessarily, unless the event is managed appropriately. Adverse response to caldera unrest may take the form of the release of inappropriate advice, media speculation, unwarranted emergency declarations and premature cessation of economic activity and community services. A non-volcanic-crisis time provides the best opportunity to develop an understanding of the caldera unrest phenomena, and the best time to establish educational programmes, funding systems for enhanced emergency response and volcano surveillance and to develop co-ordinated contingency plans.
\end{abstract}

\section{INTRODUCTION}

Changes in a number of monitored indicators (earthquakes and uplift) at two of New Zealand's active volcano caldera systems in 1998, Taupo and Okataina, resulted in increased public, local and central government awareness, coupled with some public and official concern and uncertainty about the implications and potential significance of volcanic unrest at a caldera volcano.

Caldera unrest is marked by physical changes at a caldera volcano which are often large enough to create public awareness of them (e.g. felt earthquakes). Caldera unrest is not necessarily indicative of an impending eruption. The changes may comprise earthquake activity, ground deformation, increased heat flow (thermal heating), changes in gas and fumarolic discharges and hydrological perturbations. They may not lead to an eruptive crisis, but periods of mild unrest themselves can present a range of hazards and have social implications, and therefore require a careful and managed response. Global incidences of unrest were thoroughly documented by [1] but the concept that

Institute of Geological and Nuclear Sciences, Wairakei Research Centre, Private Bag 2000, Taupo, New Zealand

Department of Geology, University of Hawaii, USA

School of Psychology, Massey University, Palmerston North, New Zealand

Institute of Geological and Nuclear Sciences, Lower Hutt, New Zealand

Consulting Economist, Wellington, New Zealand 
precursors to a potential eruption could be damaging phenomena in their own right gained credence only with the episodes at Rabaul in 1983-1984 and Campi Flegrei in 1970 and 1982-1984.

As New Zealand has several caldera volcanoes (Fig. 1), including two of the most active rhyolitic systems in the world (Taupo and Okataina), caldera unrest must be treated as a significant component of the New Zealand hazardscape. Given the rarity of caldera eruptions [2], detailed analysis of unrest accompanying historic events has an important role to play in regard to understanding the social impacts of volcanic hazards and developing a capability to manage infrequent large scale, geographically-dispersed hazards. The scarcity of large-scale caldera activity creates special problems in planning for managing volcanic crises.

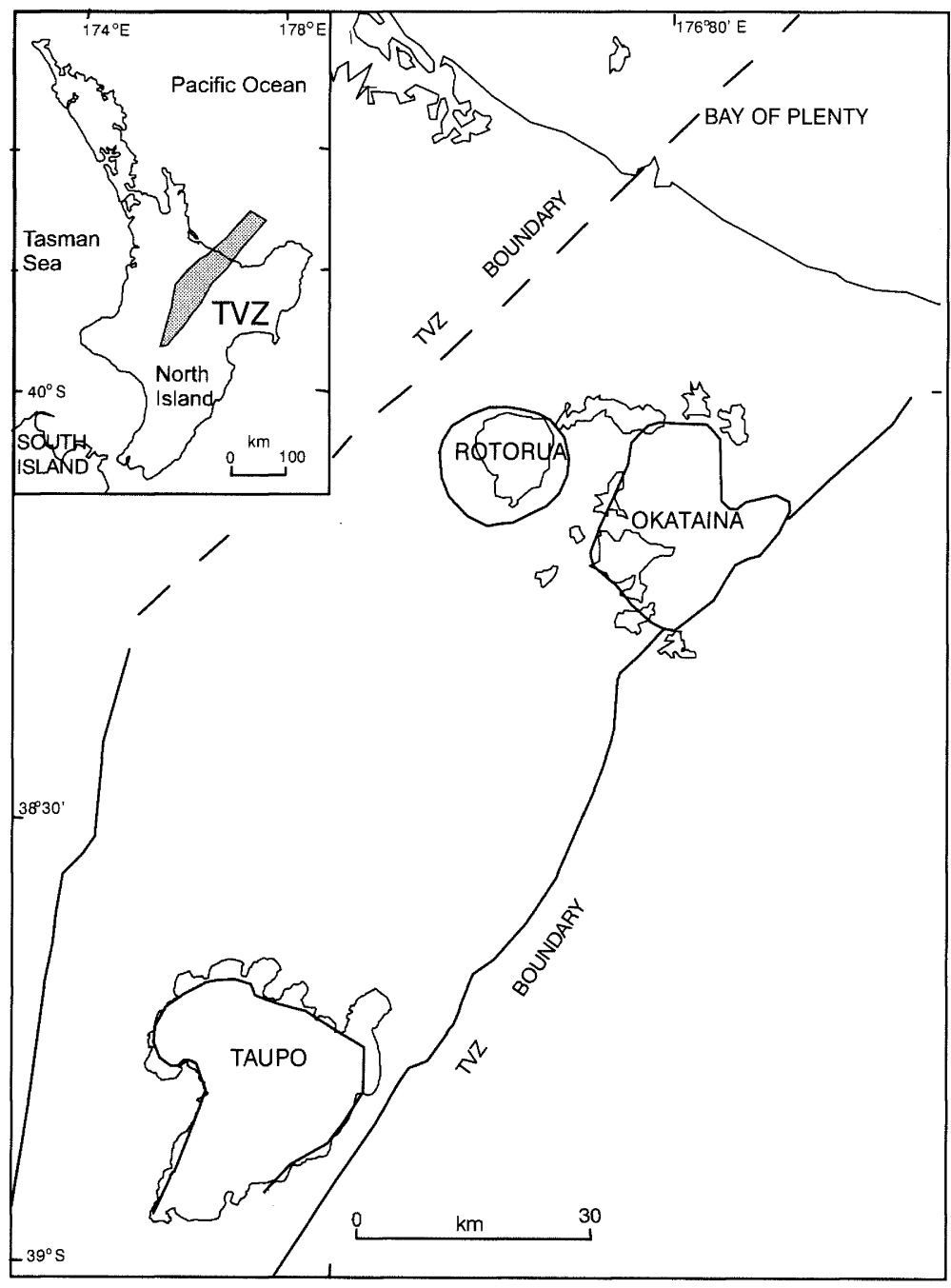

Figure 1. Map of structural boundaries of the Rotorua, Okataina and Taupo calderas in the central Taupo Volcanic Zone (TVZ). Top left inset: position of the TVZ on the North Island of New Zealand.

Integrating the analyses of prior caldera unrest with current social and management perspectives is important in other respects. For example, comparison of the 1945 and 1995 eruptions at Ruapehu volcano, illustrated how patterns of community, economic, and infrastructure development have significantly increased social vulnerability to volcanic hazard effects [3]. Historical analyses of caldera activity, and the integration of community and management perspectives within this analysis, provides a solid foundation for understanding the full implications of this kind of activity in New Zealand. It also provides a basis for reviewing the multi-jurisdictional and multi-disciplinary management context; illustrates the nature, intensity, diversity and duration of consequences to be managed; and raises issues that affect all facets of New Zealand society (e.g., urban and rural economic disruption and loss, lifeline disruption, public health and business losses).

This paper reviews the historic periods of unrest at the Taupo volcano and concludes with a discussion on the social implication of future unrest at Taupo and other calderas world-wide.

\subsection{Types of Unrest}

The first measurable changes at a caldera volcano are usually detected by geophysical or geochemical monitoring conducted as part of a volcano surveillance programme, and may not be noticed by members of the public. Unrest indicators can include events such as earthquake swarms, 
moderate sized discrete earthquakes, ground surface deformation. changes in heat flow at hot springs, gas output or chemistry, and magnetic and gravity changes. As these develop in intensity the public can soon become aware of the developing unrest. They typically reflect a combination of purely tectonic (caldera-fault-related), volcanic and hydrological processes. It is not possible, in most cases, to classify the early stages of unrest as purely volcanic or tectonic. As caldera unrest moves from the initial signs into a volcanic crisis (i.e. a potential eruption threat is recognised), then the situation becomes clearer and management options are better defined. Newhall and Dzurisin [1] have reviewed aspects of caldera unrest and identified a range of causative processes. Table 1 lists the types of unrest that may be observed and the hazards associated with them.

Predominantly tectonic processes acting on fault lines result in ground and subsurface deformation (tectonic strain) and accompanying earthquakes, unassociated, except geographically, with the presence of a caldera volcano. However dissipation of tectonic strain may be focused at a caldera, because the caldera structure and conduit system are weak points in the earth's crust. In a caldera setting, the deformation-strain process can cause volume or pressure changes in a magma body, which may initiate volcanic unrest.

Table 1: Types of unrest that may be observed and resulting hazards.

\begin{abstract}
Earthquakes (seismicity)
Hazards

Ground deformation

Hazards

Thermal changes

Hazards

Chemistry of fluids

Hazards

Magnetic changes

Hazards

Gravity changes

Hazards

Instrumentally recorded earthquakes are common at caldera volcanoes. They can occur as small to moderate size single events or in swarms of 10's or 100's of earthquakes per day. Many are felt by people.

Ground shaking causing public anxiety, larger events can injure people and damage property/infrastructure

Ground deformation can range from dramatic changes in the level of the land that can be easily seen (metres) to subtle changes $(\mathrm{mm}$ ) that can only be detected early by precise measurements.

Damage to property/infrastructure, drowning/raising of lake shores, increased river flows, damming of rivers, blockage of roads - height changes could affect flow in water supplies, sewerage systems.

Temperatures of hot springs, crater lakes, soil, and gas vents (fumaroles) may increase. Rising temperatures may be buffered by ground water and therefore may not initially reflect the change in heat flow at depth.

Hydrothermal eruptions causing injury to people and damage to property/infrastructure. Expansion of hot ground causing damage to property/infrastructure, killing of vegetation (crops/forests).

Changes are commonly recorded in the composition of gas vents (fumaroles) and hot springs.

Release of $\mathrm{CO}_{2}, \mathrm{H}_{2} \mathrm{~S}$ and $\mathrm{SO}_{2}$. Potentially harmful to people and faunalflora if released in sufficient concentrations.

As large volumes of molten rock accumulate the magnetic field recorded at the earth's surface above them will decrease.

Nil

Instrumentally detected changes in the strength of the gravitational field and can result from uplift, subsidence or the change in the average rock density (e.g. intrusion of magma into a basement of differing density).

Nil
\end{abstract}

Purely volcanic precursors may be caused by the intrusion of new magma (molten rock) into the base of a caldera magma reservoir, and/or movement of magma outward from a caldera magma reservoir into the conduit system below the volcano. This can lead to heating and partial melting of surrounding country rock. These processes in turn trigger seismic activity and changes to the discharge patterns of geothermal systems.

Hydrological processes predominantly relate to changes in pore pressures in groundwater aquifers. There may be changes in the discharge-recharge balance of ground water systems including rivers and lakes. 


\subsection{Magnitude, Frequency and Duration of Caldera Unrest.}

Unrest at caldera volcanoes is a common occurrence worldwide. Over the past 100 years there have been over 60 episodes of unrest recorded at calderas [1]. However, less than $20 \%$ have led to eruptions. Five of the more wellstudied calderas which have undergone periods of unrest are Long Valley and Yellowstone (USA), Campi Flegrei (Italy), Kutcharo (Japan), Rabaul (Papua New Guinea), with only Rabaul erupting (in 1994). A brief summary of these unrest episodes is given in Table 2 and shows clearly that although typically prolonged on a scale of years to decades, but are statistically unlikely to culminate in an eruption.

However, the social and economic impacts of the recent more intense periods of unrest have themselves been very significant. These have ranged from business down-turn in the tourism-ski industry at Mammoth Lakes in the 1980's, to the temporary evacuation of 40000 people from Campi Flegrei, in 1982-1984. Unrest preceding the 1994 eruption in Rabaul lasted over 20 years, with the insurance and finance industries limiting their exposure for a period commencing 10-12 years before the eruptions started.

Table 2: Summary of unrest at five overseas caldera volcanoes.

\begin{tabular}{|c|c|c|c|}
\hline $\begin{array}{l}\text { Unrest } \\
\text { period }\end{array}$ & $\begin{array}{l}\text { Caldera } \\
\text { Volcano }\end{array}$ & Unrest Observations & References \\
\hline $\begin{array}{l}1980- \\
\text { continuing }\end{array}$ & $\begin{array}{l}\text { Long Valley } \\
\text { (USA) }\end{array}$ & $\begin{array}{l}\text { Major unrest started with enhanced earthquake activity Oct } \\
1978 \text {, culminated in three events of } \mathrm{M} \approx 6 \text { (May 1980). } \\
\text { Thereafter, uplift was measurable and enhanced earthquake } \\
\text { activity has continued, without an eruption. More recently, } \\
\text { high } \mathrm{CO}_{2} \text { gas flux has killed off forested areas. }\end{array}$ & 29,40 \\
\hline $\begin{array}{l}1900 \text { 's- } \\
\text { continuing }\end{array}$ & $\begin{array}{l}\text { Yellowstone } \\
\text { (USA) }\end{array}$ & $\begin{array}{l}\text { Continuing unrest over the past century, consisting of } \\
\text { earthquake swarms, deformation and variations in heat flow } \\
\text { from the geothermal systems. }\end{array}$ & 41 \\
\hline $\begin{array}{l}1970- \\
\text { continuing }\end{array}$ & $\begin{array}{l}\text { Campi Flegrei } \\
\text { (Italy) }\end{array}$ & $\begin{array}{l}\text { Located in a heavily populated region near Naples, unrest } \\
\text { started in } 1970 \text { with earthquake swarms and uplift, and } \\
\text { became very intense in 1982-84. During the height of the } \\
\text { crisis, volcanic seismicity resulted in collapse of older } \\
\text { structures, prompting temporary evacuation of } 40000 \\
\text { people. To date over } 3 \mathrm{~m} \text { of uplift and subsidence has } \\
\text { occurred. }\end{array}$ & 25,42 \\
\hline $1936-1975$ & $\begin{array}{l}\text { Kutcharo } \\
\text { (Japan) }\end{array}$ & $\begin{array}{l}\text { Nine periods of unrest }(1938,1959,1961,1963,1965,1967 \text {, } \\
1968,1971,1975) \text { without eruption. Earthquake swarms are } \\
\text { very common. }\end{array}$ & 1 \\
\hline $1972-1994$ & $\begin{array}{l}\text { Rabaul } \\
\text { (Papua New } \\
\text { Guinea) }\end{array}$ & $\begin{array}{l}\text { Unrest started } 1968-69 \text { with about } 60 \text { earthquakes/month. } \\
\text { This increased to } \approx 240 / \text { month after } 1972 \text {, reaching over } \\
5000 / \text { month by } 1983 \text {. During the height of } 1983-84 \text { crisis, } \\
\text { officials issued a Stage } 2 \text { Alert and were prepared to order } \\
\text { evacuations of the populace. Crisis abated after issuance of } \\
\text { alert, and monthly earthquake activity returned to } 200 / \text { month } \\
\text { until } 1991 \text {, then rose to } \approx 800 \text { /month. Eruptions finally } \\
\text { occurred in 1994, with little immediate warning ( } 27 \text { hours). } \\
\text { Minor eruptions and lava flows continue to date. }\end{array}$ & $28,35,37,43$ \\
\hline
\end{tabular}

In the past 184 years, a range of unrest and eruptive events have occurred at New Zealand calderas. The largest being the 1814 and 1870 Raoul Island eruptions, with the most damaging being the 1886 Tarawera rift eruption (Okataina) which claimed at least 108 lives. This paper summarises the less well-publicised episodes of unrest recorded at Taupo caldera since 1895. At Taupo there have been four sequences of events (1895, 1922, 1963-64 and 1983) that have included earthquake activity and ground deformation. These events are summarised in Table 3 where the likely Scientific Alert Levels (Table 4) now in use in New Zealand have been applied retrospectively.

\section{THE TAUPO VOLCANO}

The Taupo volcano is regarded as the most active rhyolite volcano in the world [4]. It has been in existence for more than 65000 years, a very early record dating back to 320000 years is somewhat obscure. The eruptions are notable for varying enormously in size, from $<0.01 \mathrm{~km}^{3}$, up to the largest $(26500$ years ago), which ejected about $1100 \mathrm{~km}^{3}$ of material. Erupted 
magma has been dominantly rhyolite, with minor volumes of basalt, andesite, and dacite. Pyroclastic deposits outweigh lava flows by a factor of ten. Between 65000 and 27000 years BP a series of at least 5 explosive enuptions occurred from vents now beneath Lake Taupo [5]. The exceptionally large 26500 year BP Oruanui eruption erupted $\sim 1100 \mathrm{~km}^{3}$ of rhyolitic ash and pumice, whilst associated caldera collapse formed the basin now occupied by Lake Taupo [6]. Following this enuption, the behaviour of the Taupo volcano altered with the ascent of a new magma batch to shallower crustal levels. Twenty-eight eruptions have been identified at Taupo since 26500 years ago, of very different sizes and spaced at irregular intervals [5]. Twenty of these events involved interaction between lake water and magma, producing fine-grained ash fall deposits, whilst three generated pyroclastic flows. The most recent eruption, in $\sim 181 \mathrm{AD}[7]$, was the largest and most complex in this period, emplacing an ignimbrite that devastated $20000 \mathrm{~km}^{2}$ and forming a second caldera structure nested in the northeastern part of Lake Taupo. The variability in the sizes $\left(0.01\right.$ to $35 \mathrm{~km}^{3}$ dense-rock-equivalent) and repose periods (50 - 5000 years) of the eruptions in this timeframe makes it impossible to predict the timing and magnitude of the next volcanic episode.

The Taupo volcano is also being actively deformed by the broad-scale tectonic processes associated with extension of the central North Island. Extension rates are estimated at 1.9 $\mathrm{mm} / \mathrm{year}$ in the near surface and increase to a best estiimate of $6.4 \mathrm{~mm} /$ year at depths of $6-10 \mathrm{~km} \mathrm{[8].} \mathrm{It} \mathrm{is} \mathrm{these}$ processes that have driven the historic unrest described in this paper

Table 3: Unrest at New Zealand calderas in the past 184 years.

(Possible alert level shown in [ ] )

\begin{tabular}{|c|c|}
\hline Caldera Volcano & Remarks \\
\hline \multicolumn{2}{|l|}{ OKATAINA } \\
\hline 1886 & Basaltic rift eruption, 108 lives lost [Level 5]. \\
\hline $1900-1904$ & Phreatic eruptions at Waimangu (Tarawera volcano), claimed two lives $\left[1^{+}\right]$. \\
\hline $1906,1915,1917,1973,1981$ & $\begin{array}{l}\text { Hydrothermal eruptions at Waimangu (Tarawera volcano), } 1917 \text { claimed two lives and } \\
\text { destroyed a guest house }\left[1^{+}\right] \text {. }\end{array}$ \\
\hline $1983-85$ & $\begin{array}{l}\text { Earthquake activity south of the caldera, regional tilting of ground. Earthquake damage } \\
\text { claims exceeded } \$ 29000 \text { in } 1983 \$ \text {. (Smith } \text { et al., 1984) }\left[1^{+}\right] \text {. }\end{array}$ \\
\hline 1998 & $\begin{array}{l}\text { Earthquake swarm under Haroharo lava domes, and earthquake swarms south of the } \\
\text { caldera }\left[1^{-}\right] \text {. }\end{array}$ \\
\hline \multicolumn{2}{|l|}{ TAUPO } \\
\hline 1895 & $\begin{array}{l}\text { A large earthquake (Mag. } \sim 6+\text { ) followed by an aftershock sequence that lasted three to } \\
\text { six weeks }\left[1^{-}\right] \text {. }\end{array}$ \\
\hline 1922 & $\begin{array}{l}\text { Earthquake swarm lasting nine months. Displacement of up to } 3 \mathrm{~m} \text { occurred on faults on } \\
\text { the northern shore of Lake Taupo }\left[1^{+}\right] \text {. }\end{array}$ \\
\hline 1964-1965 & $\begin{array}{l}\text { Swarm of over } 1100 \text { earthquakes (Mag. }>2.5 \text { ). Focal depth less than } 10 \mathrm{~km} \text {. Uplift on the } \\
\text { northern shores of Lake Taupo }\left[1^{+}\right] .\end{array}$ \\
\hline 1983 & $\begin{array}{l}\text { Earthquake swarm between February and March } 1983 \text { accompanied by uplift and faulting } \\
\text { on the northern shores of Lake Taupo }\left[1^{+}\right] \text {. }\end{array}$ \\
\hline $1997-1998$ & Earthquake activity accompanied by uplift in later part of $1997\left[1^{-}\right]$. \\
\hline \multicolumn{2}{|l|}{ RAOUL ISLAND } \\
\hline 1814 & Eruption in Denham Bay, island formed [4]. \\
\hline 1870 & Eruptions at two sites, two islands formed, people evacuated [4]. \\
\hline 1886 & Submarine eruption, produced large pumice rafts $\left[3^{+}\right]$. \\
\hline 1964 & Eruption preceded by earthquakes and $6 \mathrm{~m}$ lake level rise. Island evacuated [4]. \\
\hline 1993 & Earthquake swarm, $1.2 \mathrm{~m}$ lake level change. Island evacuated $\left[1^{+}\right]$. \\
\hline
\end{tabular}

\section{1895 SEISMIC EVENT}

The 1895 earthquake activity lasted a few weeks and caused ground cracks, subsidence and rock-slides around Lake Taupo (Figs. 2,3). A large earthquake occurred around $6.27 \mathrm{pm}$ (local time) on 17 August that was felt at Napier, Hamilton and
Gisborne. Eiby [9] reported damage indicating Modified Mercalli VIII (MM8) or more in Taupo and landslides and fissures in the Wairakei area. These observations suggest an earthquake with magnitude $>6$ [11], although not as large as magnitude 7.5 as suggested by Eiby [9]. Hill [10] reported "the isolated hill known as [Maunganamu], about three miles to the 
eastward of the lake, was split in parallel lines that ran northeast and south-west". Grindley and Hull [11] attribute these fissures to the line of a concealed fault. It was reported that the earthquake was accompanied by a "2 foot high wave" on Lake Taupo (Auckland Star, 20 August 1895).

Although data on this event is limited it appears more likely to be a main shock-after shock sequence rather than a typical earthquake swarm sequence. The event appears to be comparable in magnitude to the 1986 Edgecumbe earthquake [12].

\subsection{Physical consequences}

In Taupo "most chimneys were down, and crockery and glassware was broken" (The Press, 20 August 1895), however no injuries were reported. "In the hotels and stores nearly all bottles were smashed, and crockery suffered severely everywhere" the Auckland Star (19 August 1895) reported. The earthquake caused major damage to the principal road south of Taupo (Fig. 3) and opened several fissures south of Mt Tauhara and Maunganumu [10].

\subsection{Public response and media coverage}

The first night after the earthquake most people were said to be camping out in tents (Auckland Star, 19 August 1895). There is little evidence that this persisted for more than a few days. By 2 September it was reported, "the hotelkeepers have nearly obliterated all marks of damage" (Auckland Star, 2 September 1895). The official response was limited to government scientists giving explanations of the events in the national newspapers.

The earthquake was reported widely in the national newspapers and reports of the aftershocks continued for at least two weeks in the same newspapers (e.g. Auckland Star). Several stories described the perceived link between the cone volcanoes to the south (Ruapehu and Tongariro) and the earthquake activity. A sub-headline in the Auckland Star on 19 August stated "VOLCANIC DISTURBANCE AT TAUPO". The paper went on to report "Some miles south of Taupo stands the great snow covered volcanic mountains, Ruapehu, Tongariro and Ngauruhoe, which are intermittently very active. It is possible some disturbance at these volcanic vents which has caused the earthquake.... There are numerous fumaroles and steam holes which serve as "safety valves" close to Taupo, and it has been noticed that these have been unusually active just after an earthquake" (Auckland Star, 19 August 1895). Four days after the earthquake it was reported that Tongariro was "suddenly inactive" and this was reported to have caused alarm amongst the residents. However, eight days later (2 September) the Taupo postmaster is report as saying, "we are still having a few earthquakes, but Tongariro is steaming up merrily, and this has relieved people's minds." (Auckland Star, 2 September 1895).

Table 4: Alert level table for Taupo.

\begin{tabular}{|c|c|c|c|}
\hline \multicolumn{2}{|r|}{ SCIENTIFIC ALERT LEVEL } & \multicolumn{2}{|c|}{$\begin{array}{c}\text { For the New Zealand volcanoes of: Kermadecs, } \\
\text { Northland, Auckland, Mayor Island, Rotorua, } \\
\text { Okataina, Taupo, Taranaki }\end{array}$} \\
\hline LEVEL & Phenomena Observed & & Scientific Interpretation \\
\hline $\mathbf{0}$ & $\begin{array}{l}\text { Typical background surface activity; } \\
\text { seismicity, deformation and heat flow at low } \\
\text { levels }\end{array}$ & $\rightarrow$ & $\begin{array}{l}\text { Usual dormant, intra-eruption or quiescent } \\
\text { state. }\end{array}$ \\
\hline 1 & $\begin{array}{l}\text { Apparent seismic, geodetic, thermal or other } \\
\text { unrest indicators. }\end{array}$ & $\rightarrow$ & $\begin{array}{l}\text { Signs of volcano unrest. } \\
\text { No significant eruption threat }\end{array}$ \\
\hline 2 & $\begin{array}{l}\text { Increase in seismicity, deformation, heat flow } \\
\text { and/or other unrest indicators. }\end{array}$ & $\rightarrow$ & $\begin{array}{l}\text { Indications of intrusive processes. Local } \\
\text { eruption threat. }\end{array}$ \\
\hline 3 & $\begin{array}{l}\text { Commencement of minor eruptions at } \\
\text { reawakening vent(s). Relatively high and } \\
\text { increasing trends shown by unrest indicators. }\end{array}$ & $\rightarrow$ & $\begin{array}{l}\text { Increasing intrusive trends indicate real } \\
\text { possibility of hazardous eruptions. }\end{array}$ \\
\hline 4 & $\begin{array}{l}\text { Establishment of magmatic activity at } \\
\text { reawakening vents(s), with acceleration of } \\
\text { unrest indicators. }\end{array}$ & $\rightarrow$ & $\begin{array}{l}\text { Large scale eruption now appears } \\
\text { imminent. }\end{array}$ \\
\hline 5 & $\begin{array}{l}\text { Destruction within the Permanent Danger } \\
\text { (red) Zone. Significant risk over wider areas. }\end{array}$ & $\rightarrow$ & $\begin{array}{l}\text { Hazardous large volcanic eruption in } \\
\text { progress. }\end{array}$ \\
\hline
\end{tabular}

\section{1922 SEISMIC SWARM}

The Taupo earthquake swarm of 1922 extended over a period of five to six months, mainly from May to October, with thousands of small shocks being felt in the Taupo area [11, 13] (Fig. 2). Four of the largest shocks $\left(M_{W} 5-5.4\right)$ occurred on 9 June, 4 July, 14 July and 5 September [14]. These events appear to have been centred about 15 kilometres north of Taupo near Oruanui where the strongest intensities were experienced, Modified Mercalli VII (MM7), and possibly MM8 in one of the events. As well as ground shaking, various geological phenomena were observed including small landslides (Fig. 4), fault displacements of up to $3 \mathrm{~m}$, regional subsidence of 3-4 m (Fig. 5,6), and tilting of fault blocks, as reviewed by Grindley and Hull [11]. 
The main geological features associated with this earthquake swarm were broad ground deformation (mainly subsidence) and faulting. Several reports of subsidence of the northwestern shores of Lake Taupo appeared in the newspapers during the seismic activity in the area, equal to a total subsidence of $3.7 \mathrm{~m}$ between late July 1922 and January 1923. Ground cracking, fissuring and water fountaining were also reported. Fault rupture occurred on five faults over an area of $\sim 70 \mathrm{~km}^{2}$ [15]. Fault displacement on the Kaiapo Fault showed an average thrown-down to the west of $0.5 \mathrm{~m}$ with $0.3 \mathrm{~m}$ extension. Other points along the fault had less displacement. The Whakaipo Fault showed $3 \mathrm{~m}$ of displacement downthrown to the NW. On a probable splinter of Ngangiho Fault there was downthrow of $100 \mathrm{~mm}$ on the west side of its trace. Displacements on Whangamata Fault were up to $1.8 \mathrm{~m}$ downthrown to the east, and $0.3 \mathrm{~m}$ of displacement was also observed on a similar trending fault to the east of Whangamata Fault. Only cracks were reported along Puketarata Fault.

\subsection{Physical Consequences}

Despite the widespread and persistent tremors only minor damage resulted from the swarm. Damage to crockery and bottles falling of shelves were reported at Taupo and Wairakei during the entire swarm (e.g. The Auckland Weekly News, 22
June 1922). Morgan [13] noted that several chimneys $10-15 \mathrm{~km}$ north of Taupo were shaken down. Numerous slips were reported around and to the north of Taupo, with a number of roads blocked. One such slip, $\sim 10 \mathrm{~km}$ north of Taupo, narrowly missed a passing vehicle carrying eight people (Taumarunui Press, 18 July 1922). The tremors also caused "a temporary blockage near the (Spa) Hotel by fall of trees" (N.Z. Herald, 1 July 1922).

\subsection{Public Response}

The 1922 swarm led to a range of response amongst the affected population. In a letter to the Postmaster General, $\mathrm{Mr} \mathrm{H}$. Mitchell stated that "people, particularly the women are feeling the strain badly and I suggest that the post offices .......be kept open at nights, and the car proprietors instructed to keep in readiness as a measure of precaution. This would comfort the residents in the affected areas should the worst happen." After weeks of continued shaking it was reported that residents were in a "state of great anxiety" particularly following a night of severe tremors (The Auckland Weekly News, 22 June 1922). What were particularly unsettling were earthquakes at night, sometimes accompanied by a "terrifying rumbling" (The Auckland Weekly News, 22 June 1922).
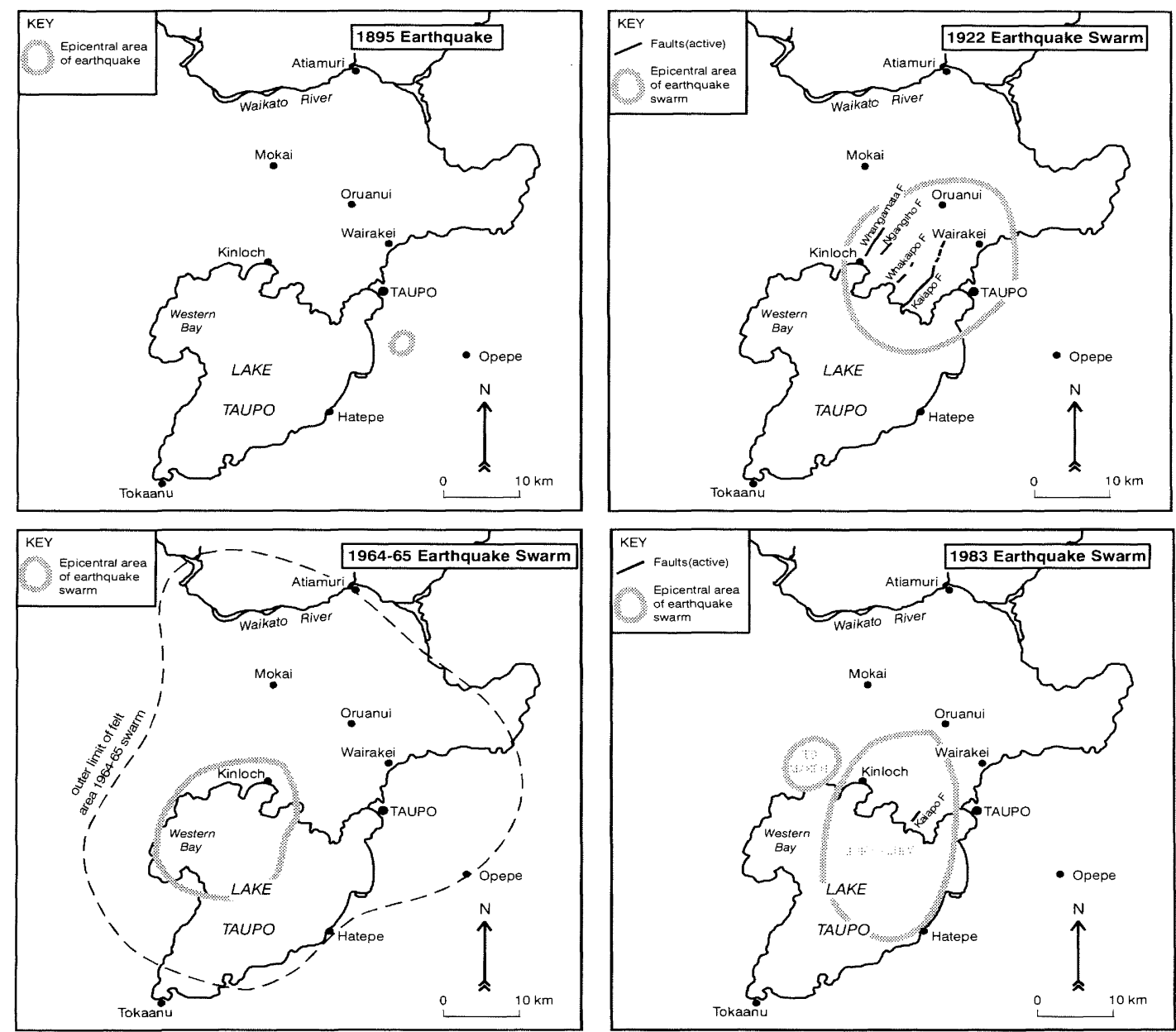

Figure 2: Map showing the epicentral area and fault movement of the 1895,1922, 1964-65 and 1983 unrest events at Taupo. Maps based on those presented by Morgan [13] and Grindley and Hull [11]. 
The uncertainty about what was happening created a large number of rumours, which were commonly reported in the newspapers. The County Press of Whakatane reported "travellers from Taupo coming through here yesterday told of a general exodus from Taupo and the expectations of a "blowup" within 24 hours. The Press made enquiries at Taupo and ascertained that while the shakes continued and were unpleasant there had not been any exodus, nor had there been any great damage" (County Press, 13 June 1922). The next day the Auckland Star reported "It is astonishing what wild rumours are flying about Rotorua and district concerning these Taupo tremblings. Matata rang up today to know if it was true that Taupo had been blown up. There were also stories of wholesale evacuation until one quite expected to see the road littered with flying residents. True some visitors made a beeline for Rotorua a few days ago when shakes were very pronounced and a tourist at Rotorua suddenly cut short what was to have been a seven weeks' visit .... but residents generally are pretty calm."

There were numerous reports of people moving out of the area during the swarms although most evidence suggests that this was a minority of the local population. One such example "became so alarmed at the possibilities lurking beneath the earth crust that he decided to get his wife out of the danger zone and arrived by motor (in Rotorua)" (Auckland Star 20 June 1922). Around 40 of the Maori population of the small sawmilling settlement of Oruanui left for nearby Mokai in mid-June (The Auckland Weekly News, 22 June 1922). The Oruanui school teachers, Mr and Mrs D.W. Miller, departed in mid-July for Rotorua (Rotorua Chronicle, 15 July, 1922).

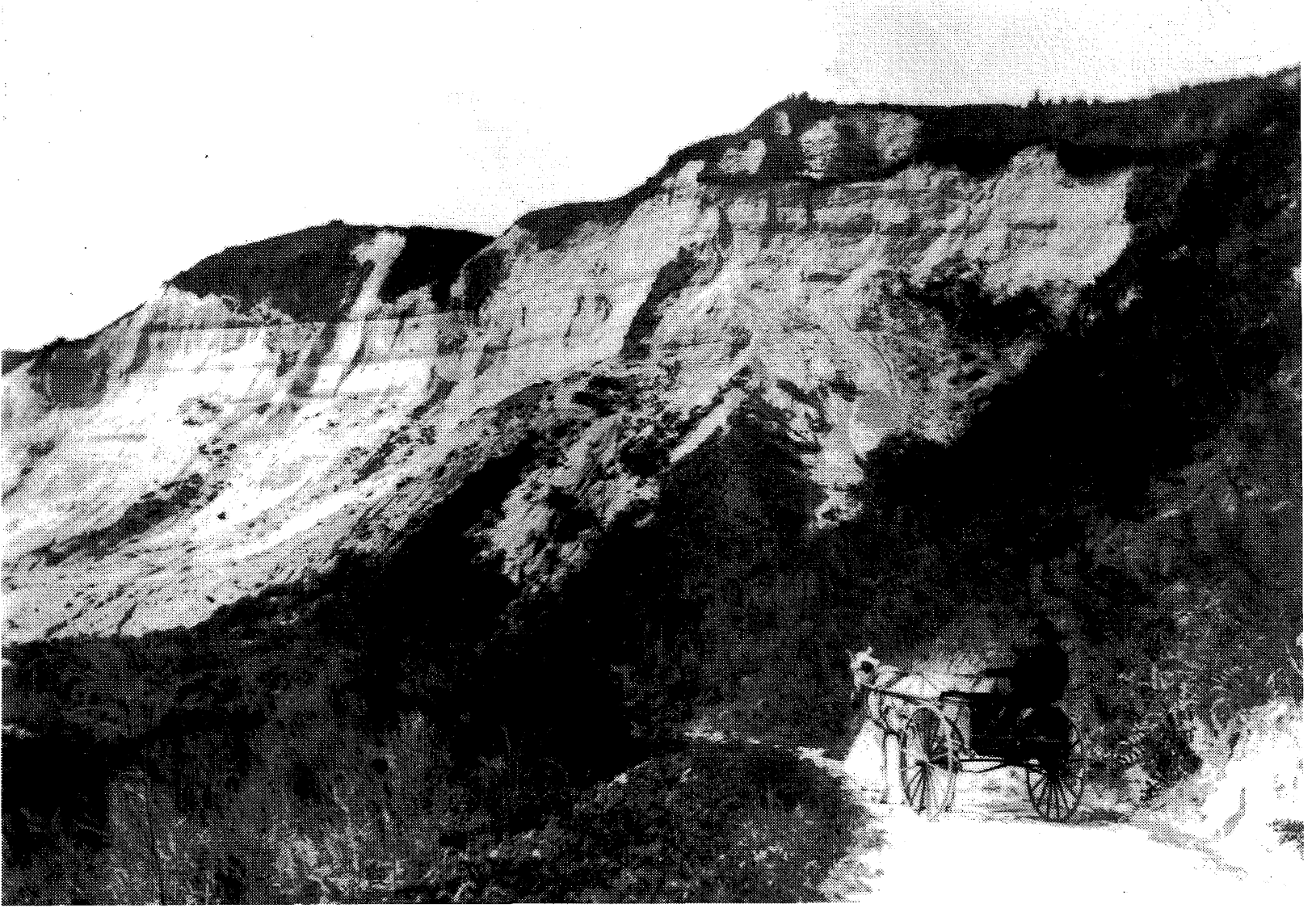

Figure 3. Landslide caused by the 17 August 1895 earthquake. The road south of Taupo township was blocked by this event for several days. The location became known as "Earthquake Gully". Photograph taken in 1897 by unknown photographer. From collection of the Taupo District Museum.

It was reported that most visitors to the area had left "some in haste" during June (The Auckland Weekly News, 15 June 1922). On 1 July 1922 the N.Z. Herald reported that "no tourists are remaining at Wairakei and the parties that do arrive there invariably leave at dawn the next day. However some visitors continued to come to the area".

The drop in visitor numbers to Taupo and Rotorua cause financial losses to both communities. In the case of Rotorua it was due largely to exaggerated and/or false media reports (see later).

\subsection{Media coverage}

The Taupo unrest of 1922 was widely reported in the national and some international newspapers. Despite the reported public alarm many articles carried statements from local residents downplaying the levels of anxiety in the community and at times criticising many of the earlier stories. The postmaster at Taupo, Mr Barker reported in June that "there is a fair amount of nervousness among residents, but generally they are optimistic and although they do not like earthquakes they are not going to clear out" (The Auckland Weekly News, 22 June 1922). 
There was considerable concern expressed at the mis-reporting of the events in Australian papers, which stated that disturbances had occurred at Rotorua (N.Z. Times, 3 July 1922). As Rotorua had not experienced any earthquakes local tourism operators were naturally upset by the drop in visitor numbers that such reports caused (Rotorua Chronicle, 4 July 1922, Auckland Star, 6 July 1922).

\subsection{Official response}

A number of newspaper editorials criticised the lack of support that central government (Parliament) had given to the study of earthquakes and volcanic activity in New Zealand. Calls for improving the observations of such phenomena were common (e.g. N.Z. Herald, 6 June 1922). In early June the government sent a scientific team up from Wellington in response to the reported alarm of local people to the felt earthquakes (Auckland Star, 10 June 1922). The Post Offices also played an important role during the unrest by way of providing communication into and out of the area.

There was concern expressed at the time about the lack of telegraphic communications with Taupo at night. The postal authorities stated that "the telephone office could always be opened on request to the Taupo telephonist, who lived on the premises. He would be able to communicate either with Napier or Rotorua, both of which had continuous services" (The Auckland Weekly News, 15 June 1922).

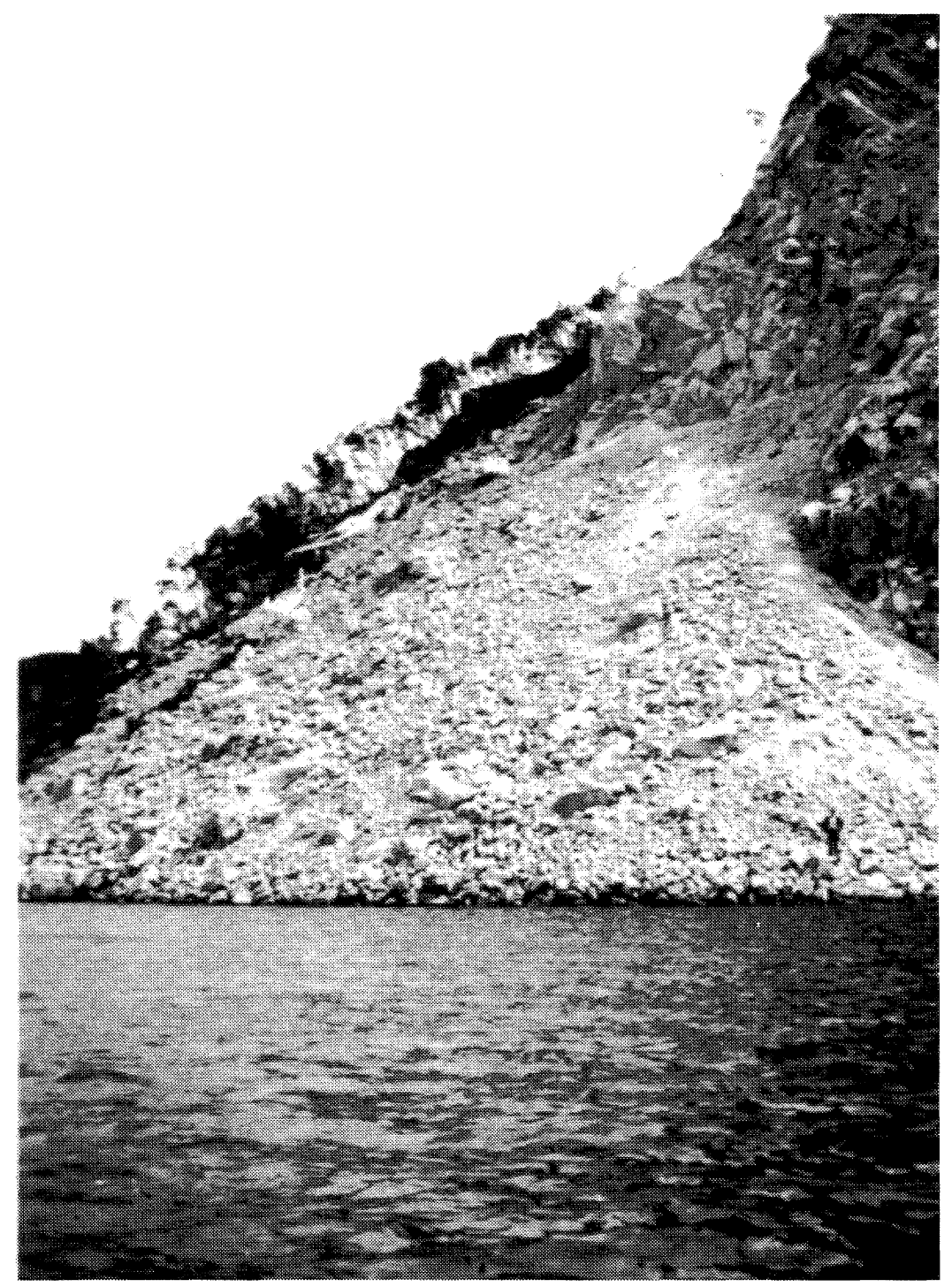

Figure 4: Landslide at the head of Whakaipo Bay formed during the 1922 swarm. Photograph taken in March 1923. $R$ Gerard Ward collection, Taupo Library. 


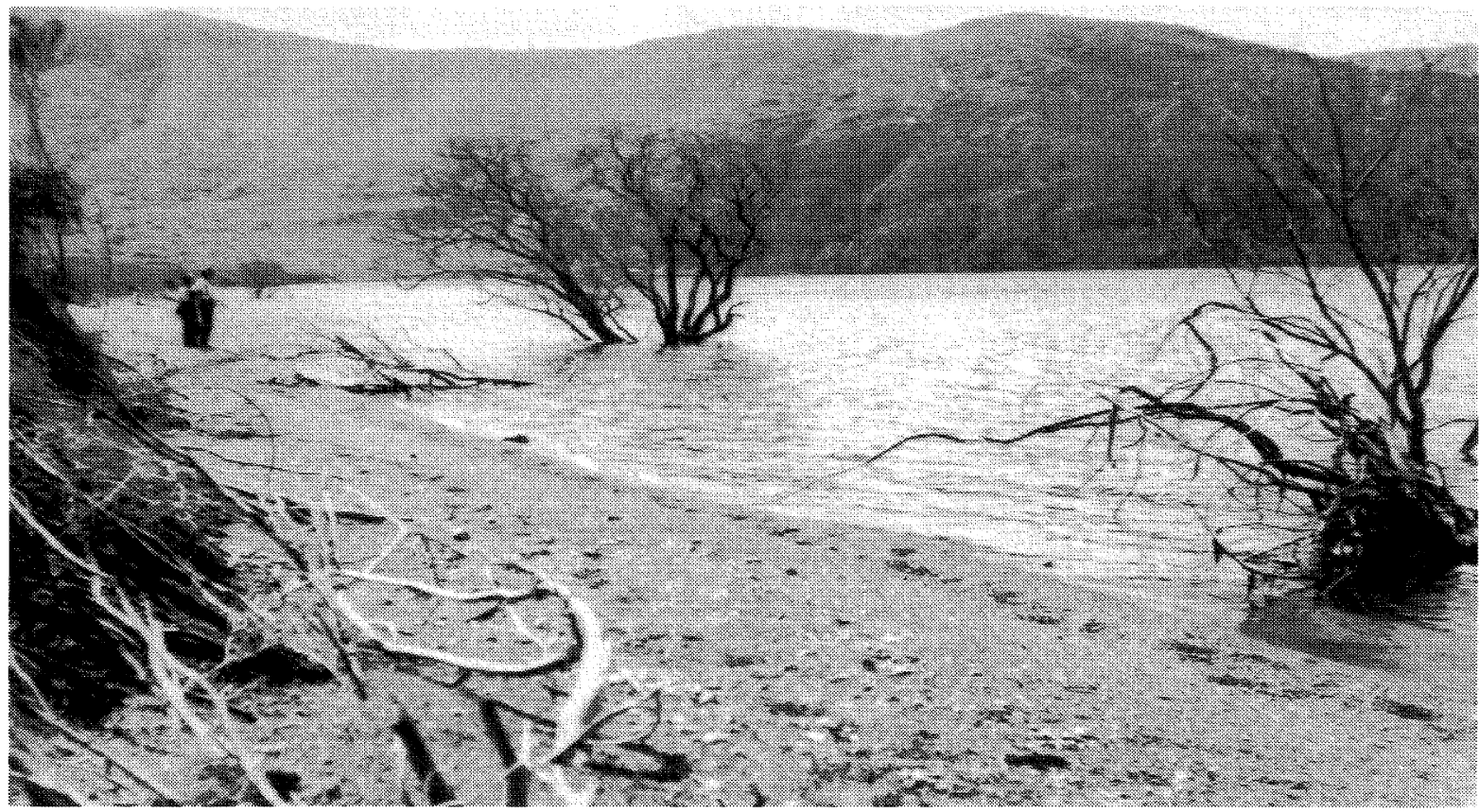

Figure 5: Subsidence in Whakaipo Bay area during the 1922 earthquake swarm resulted in the partial submergence of several trees. Photograph taken in March 1923. R Gerard Ward collection, Taupo Library.

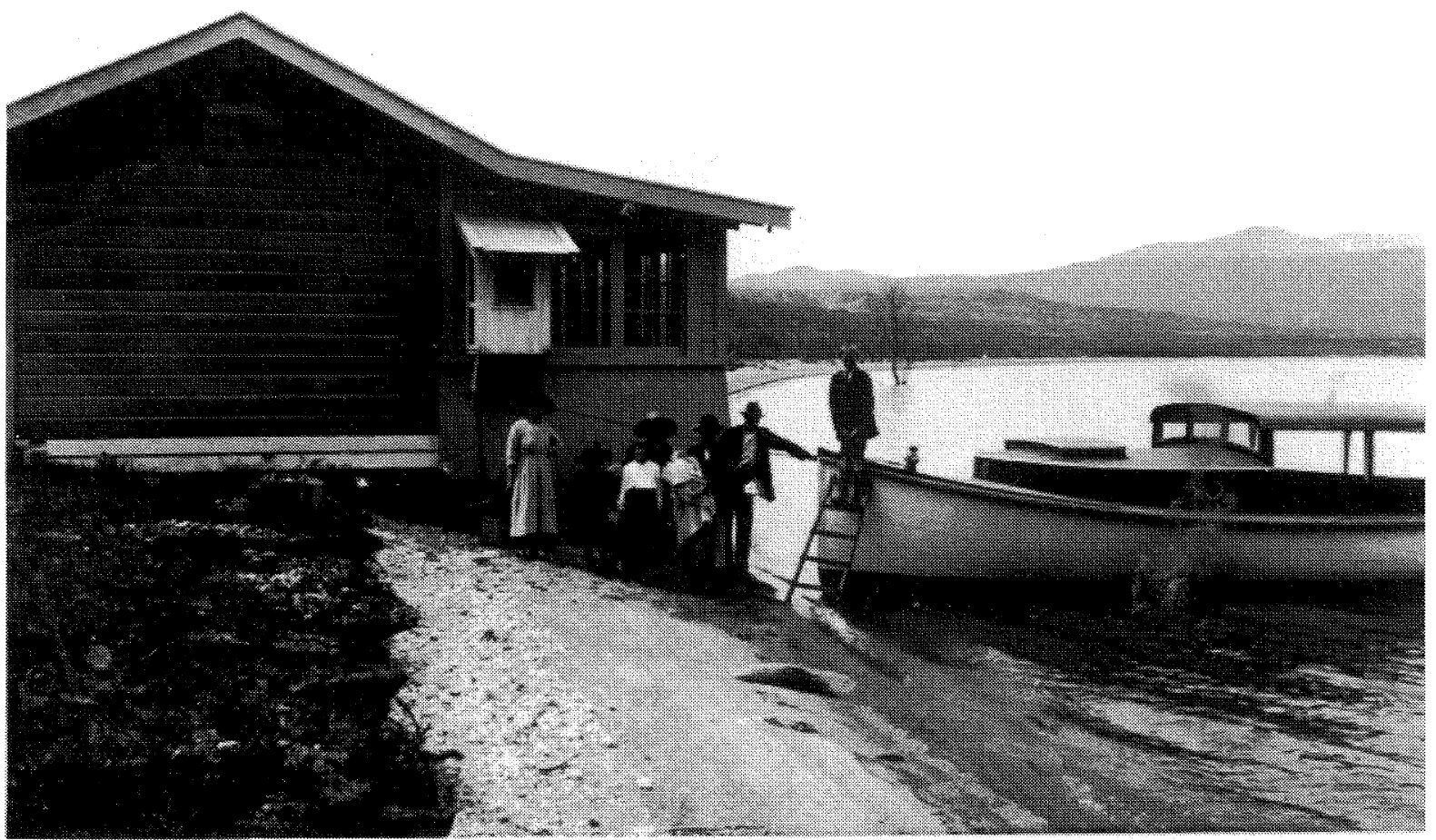

Figure 6: The launch 'Tuwharetoa' pulled up right outside the Internal Affairs fishing lodge at Whakaipo Bay. Subsidence during the 1922 earthquake brought the lake right to the door of the cottage. R Gerard Ward collection, Taupo Library.

\section{1964-1965 SWARM}

Unlike the 1922 swarm, the 1964-1965 earthquake swarm was instrumentally well recorded because of the development of the National Seismograph Network. No fault displacements, ground uplift or subsidence were recorded for this swarm, but no detailed investigation was conducted [11]. The area where this swarm was felt was about half the radius of that for the 1922 swarm (Fig. 2).

Seismic activity commenced on 4 December, with two peaks in activity on 12 December and 21 December. From mid-January 1965 on the activity was sporadic and an isolated earthquake (M =4.6) occurred in mid August, $7-8 \mathrm{~km} \mathrm{NW}$ of Wairakei, 
followed by an increase of activity through October, November and December.

No fault displacements or ground deformation were reported at the time, but a mean rise of $90 \mathrm{~mm}$ of a block to the south-east of the Taupo Basin was obtained from the comparison levelling data along SH1 (Taupo-Turangi) in 1956 and 1977. Grindley and Hull [11] suggested that these changes may have occurred in association with the 1964 swarm.

\subsection{Public and official response}

Little physical damage was reported during the entire swarm event; however, high levels of anxiety and uncertainty existed in parts of the community. Residents at the time ( 12 were interviewed between September 1998 and February 2000) recalled varying degrees of concern among individuals and families. Most stated that initially people felt "on-edge" but that most residents became used to the earthquakes with time. However, there is anecdotal evidence that several residents moved out of the district or were said to be "close to leaving town". One local Real Estate agent reports that they received a few cancellations of holiday accommodation in Taupo from people outside the area but this only occurred with a minority of their bookings. Some of the residents interviewed recalled discussion in the community about the possible link between the earthquake swarm and the volcano but few felt that this was a major issue at the time. Scientific staff at the DSIR's Wairakei Research Centre were commonly cited as providing information on what was happening.

\subsection{Media coverage}

The swarm was reported in both local and national newspapers during December 1964 and January 1965 (e.g. headline in the NZ Herald 9 December 1964: "Series of Earth Tremors in Taupo District"). Official comment was frequently reported from the Seismological Observatory in Wellington. The media coverage reported little evidence of concem amongst the affected population. On 17 December the NZ Herald reported, "Hotel owners and tourist agents have reported no cancellations of bookings." On 23 December the Taupo Times (the local newspaper) ran an article on the 1922 swarm in an attempt to put the current swarm in perspective. In January $1965\left(26^{\text {th }}\right)$ the same paper reported varying opinions as to the economic effect of the December earthquakes stating that the manager of the public swimming pool had reported a drop in attendance, blaming "fine weather and the exaggerated reports of earth tremors". However, the caretaker of the municipal campground reported "the earthquake scare, which played up considerably before the holiday period hardly affected the number of people who passed through the camp over Christmas".

\section{1983 SEISMIC SWARMS}

The 1983 swarms took place in two stages (Fig. 2). The Motumoa swarm extended from 4 February to early March, with the largest shock $(<M=3.7)$, recorded on 4 February, located $2 \mathrm{~km}$ west of Motumoa and at a depth of $5 \mathrm{~km}$. Very small earthquakes were located using portable seismographs and show depths of 4-8 km for the 16-19 February earthquakes. The Kaiapo swarm started on 16 June and lasted about a month. The largest events were felt from Kinloch to Acacia Bay. The largest earthquakes were later relocated further east and they seem to lie on or close to the Kaiapo Fault [11]. Portable seismographs recorded earthquakes of M 2.5 to 4.3 (the largest one on 1 July was located about $5 \mathrm{~km}$ south of Kaiapo Bay). The depth range for these earthquakes lies between 6 and 10 $\mathrm{km}$. Some earthquakes seemed to cluster to the southeast along the Horomatangi Fault, and along a line from Motutaiko Island to the Waihi Fault.

The ground deformation associated with these swarms took place in three different stages [16]. Three months prior to commencement of the seismicity on 16 June uplift was found to be occurring along the northern shoreline, reaching $53 \mathrm{~mm}$ by 13 June at Kinloch near the centre of the Taupo Fault Belt. During the earthquake activity rapid subsidence occurred to the west of the Kaiapo Fault and had reached 55 $\mathrm{mm}$ at Kinloch by the time activity ceased about mid July. The Kaiapo Fault, a west-dipping normal fault, ruptured during a strong earthquake on 23 June with a $<50 \mathrm{~mm}$ downthrow to the west and a $<30 \mathrm{~mm}$ extension along a 1.2 $\mathrm{km}$ section [11]. Vertical deformation surveys revealed that tilting occurred on the western side of the fault in association with the rupture [16]. Following the swarm uplift was found to be continuing at a steady rate in the block east of the fault, apparently uninterrupted by the seismicity although movement elsewhere had virtually ceased. By the time uplift east of the fault ceased in December this block was found to have been raised 30-40 $\mathrm{mm}$ above its pre-1983 level [16].

\subsection{Public Response and Media Coverage}

The 1983 swarm was the smallest of the four events described in this paper and correspondingly generated the least public response. Only a few earthquakes were felt in central and eastern parts of Taupo township, with a greater number felt in the Acacia Bay area. Little damage was reported apart from the rupture of the Kaiapo Fault across Mapara Road.

The 1983 earthquake swarm received the least coverage of the four events described in this paper. Several articles in the Taupo Times describe the swarm and the monitoring activities undertaken by the DSIR. On 28 June the Taupo Times headlines with "Deep Crack Appears in Quake-Zone Farmland", describing the fault rupture on the Kaiapo Fault. An article on 1922 swarm appears in the same paper on 5 July.

\section{DISCUSSION - Aspects of event response}

The four unrest episodes described in this paper, illustrated a range of physical, economic and social consequences that have occurred in the past. Although each of the four events varied in duration similar social responses were observed. Anxiety and uncertainty about what was happening were common to all events. Demand for information and advice from officials was a common issue, along with the role the media played in passing information to the public. These events and other unrest episodes elsewhere provide a useful insight into the social and management issues that will need to be addressed in any future unrest episodes.

Unrest at the Taupo caldera is expected to continue in the future. In most cases it will be caused by the broad-scale tectonic processes associated with crustal extension of the central North Island. However any future unrest event may be the precursors to volcanic activity caused by the emplacement of magma under the volcano. 


\subsection{Current and future volcano surveillance}

Taupo caldera presents a challenge to monitor as most of the volcano is inaccessible under the lake. Current monitoring is based on a 5-station seismic network and a 22-station lake levelling network. The monitoring was developed out of experimental networks established to characteristise seismic activity and develop techniques to measure ground deformations from Taupo caldera $[16,17,18]$. The experimental seismic network was operated from September 1985 to July 1991 and demonstrated the repeated occurrence of sequences of small earthquakes, especially beneath the central, eastern and southern parts of the lake. In 1995 with the assistance of New Zealand Lottery Board funding the seismic network was reestablished, with near-real-time recording at the Wairakei Research Centre. The recently funded GeoNet project, will see the sensors upgraded to 3D and digital telemetry introduced after 2002 .

Ground deformation studies started in mid-1970's with tilt levelling patterns being installed about the major faults north of the lake and experiments to see if vertical deformation could be detected by lake levelling [16]. The 1983 events demonstrated the usefulness of these techniques [19]. In 1986 a portion of the triangulation network spanning the Taupo Fault Belt immediately north of Lake Taupo was repeated and analysed to establish estimates of the horizontal deformation [20]. These results were reviewed by Darby et al [8], to take into account non-tectonic deformation attributed to Wairakei geothermal development. Currently only lake levelling surveys are routinely conducted as part of the volcano monitoring. GPS stations may be introduced as part of the GeoNet project after 2002.

\subsection{Public Alarm and Potential for Increased Perception of Risk}

Public alarm is a natural outcome of any unrest period and has been reported to some degree during all unrest episodes and should be anticipated during future unrest events. The uncertainty about what is occurring and what it means is the most common cause of alarm.

At least two studies have been undertaken after a volcanic unrest period to gain a measure of perceptions of risk and public responses. Kuester and Forsyth [21] undertook a study of volcanic risk and preparedness at Rabaul in 1984 and found an encouraging level of understanding of the hazards and evacuation plan. Following the release of the 1982 volcanic hazard "notice" at Long Valley, Bernknopf et al. [22] found that there was an increase of the perceived risk amongst property owners.

\subsection{Evacuation}

During unrest periods some residents may self-evacuate from affected areas. There is anecdotal evidence (contemporary newspaper reports and personal communications for 1964) for Taupo residents voluntarily moving out of the district as a consequence of the felt earthquakes in 1895, 1922 and 196465. A similar situation occurred in 1983-85 following earthquake swarms south of Okataina Volcanic Centre [23, 24].

In 1970 the unrest at Campi Flegrei resulted in the evacuation of 3000 people living in the old quarter of the town of
Pozzuoli, primarily due to building damage [25]. In 1983 about 40000 people were evacuated again from Pozzuoli as a result of the volcanic unrest. During the 1983-1985 period when unrest accelerated at Rabaul, a number of people voluntarily relocated to areas away from the caldera [26].

\subsection{Potential economic consequences}

There is an extensive literature illustrating the widespread economic consequences of natural disasters. Normally these effects result from a one-off destruction of capital stock and the subsequent disruption to business activity. In marked contrast, volcanic unrest has rather different impacts that are, in many respects, potentially more troublesome. Specifically, the economic effects of caldera unrest tend to be manifest mainly through increased business uncertainty and may persist for considerable periods of time (years to decades).

This is of concern because it is known that one of the determinants of economic growth or sustainability is confidence in the outlook for future economic activity. This is illustrated by the very close correlation between measures of business confidence and future rates of economic growth and investment activity [27]. By increasing business uncertainty, periods of caldera unrest may result in losses of confidence and shifts in risk perception by consumers, business operators and investors.

At a local level these adverse effects are likely to show up in a number of indicators. The most obvious is a downturn in demand. This was evident in Taupo in late 1964 when a decline in visitor numbers was reported to the district and some business owners noted a flow-on effect to lower business activity. Another example of these "demand-side" effects was the mass cancellation of tourist bookings at Mammoth Lakes that followed initial newspaper and radio reports of the possibility of an eruption at Long Valley caldera (USA) in the summer of 1982 [28].

In the case of Mammoth Lakes, by the end of 1984 (two years after the unrest started), it became clear that the hazard notice had had a relatively short-term effect, with visitor numbers having returned to pre-warning levels. And in the case of Taupo (1964-65) the business effects were manageable. However these examples highlight how initial public reactions have the potential to feed through into weakened economic activity. If these effects last long enough they may eventually result in declines in sales and profits. Certainly this was the case following the onset of the 1983 Rabaul crisis [26].

Increased risk perceptions may see falls in asset values, which may also result in capital investment decisions being postponed or cancelled. In theory, markets should accurately incorporate known risks into prices. However low probability-high loss events like earthquakes and volcanic eruptions may be different in their effects on markets. Specifically, events that increase awareness of risks might alter behaviour and prices.

In a case study examining this issue, Bernknopf et al. [22] have shown that increased natural hazards awareness following the issuing of the hazard notices at Mammoth Lakes did increase perceptions of risk. This in turn fed through into investment decisions and lower property values, even though the size of the risks involved was extremely small. Consistent with this, there was some anecdotal 
evidence that the Taupo community has shown initial signs of nervousness following the reporting of the 1998 smallscale unrest at Taupo, for example financial-management enquiries from local companies and houses being sold.

The magnitude of these effects on local business is highly variable. Their size depends on:

- The size of the threat and scales of uncertainty (i.e. extent of knowledge about the degree of risk and the likely duration of the unrest). These in turn depend on the amount and quality of the information available to local businesses, investors and consumers.

- The type of businesses affected. The nature of unrest means that recreational/tourism businesses tend to be most sensitive since in these sectors it is generally easy for demand to switch elsewhere [29].

- The underlying strength of the businesses and communities affected. Here the concerns are factors such as pre-existing debt levels and trends in business activity. One lesson from the literature on natural disasters is that they tend to exacerbate pre-existing economic trends (see e.g. [29]).

- Scale of economic activity at threat. Obviously regions with relatively large local economies face a larger threat than do others. Also, the overall scale of the economic effects depends on the degree of backward and forward linkages the region has into the wider economy [30].

- The "flexibility" of the local business sector, i.e. the extent to which they are able to work around problems, their degree of diversification and their ability to reassure investors and consumers.

A key determinant of the economic effects of such events is their impact on insurance markets. One risk with on-going unrest is that it may lead to changes in premiums or the cancellation of policies. Certainly this was the case in Rabaul (PNG) where Lowenstein [26] notes that there were "massive" increases in insurance premiums and loss of cover against volcanic and seismic risk. These insurance effects persisted through the crisis and flowed into a lack of finance from lending institutions for sustaining business activity and new developments. Also, during the recent Ruapehu unrest it is known that some insurers cancelled coverage in the region (either by activating their "7 days notice" clause or simply not renewing cover). At least one company continues to restrict volcanic coverage in the region.

If periods of unrest are significant and long lasting they may have effects even beyond the local economy. One concern is the potential flow on into higher fiscal costs, e.g. emergency expenditures, increased welfare payments, etc. In Rabaul, for instance, one of the most significant economic effects was the large amount of unbudgeted expenditure on emergency preparedness [26].

Also there is potential for misreporting by the international media. A recent example of this was the way in which the Auckland electric power crisis was widely misreported overseas. These media effects may exacerbate offshore investor unease with the danger being that investor reactions are out of proportion to the size of the risks. De Bondt and Thaler [31, 32] provide evidence of these sorts of overreactions. Similarly there is some evidence that investor risk perceptions can suddenly alter on the back of news even when economic fundamentals remain unaltered [33]

\subsection{Role of the media}

The media plays an important role during any unrest period. However, the media has frequently been criticised for the way it has reported unrest periods and is commonly accused of exaggerating the level of risk.

The Taupo unrest of $1895,1922,1964-65$ and 1983 was reported in both the local and national newspapers. A downturn in visitors to the Taupo district in late 1922 and 1964 was blamed by some local business owners on the newspaper reporting of the earthquake swarm.

In 1982 the Los Angeles Times learned of the impending US Geological Survey (USGS) notice concerning volcanic unrest at Long Valley and published a story on it prior to its official release [29]. The newspaper article was the first that local authorities had heard of the USGS notice and many were annoyed about the lack of consultation. Newspaper and radio stories that followed exaggerated the level of risk. A lack of supporting background information was blamed for some of the imaginative reporting that followed. The USGS, who are the prime agency involved in volcanic unrest assessment, took three weeks from the time of the initial release to produce follow-up material.

During the 1983-85 Rabaul crisis Lowenstein [26] reports that inaccurate and sensational reporting by the media aggravated a number of the effects on the public. This prompted the setting up of a public information unit to disseminate information. A privately published news-sheet was also produced to explain the truth and allay public anxiety.

Often during the initial stages of a developing situation, the primary responding agency can be overwhelmed by the media enquiries. This can lead to the media locating other sources for information, like academics, who can have theoretical knowledge of the topic but lack detail on the current situation, as they are not directly involved. In particular, this can be a major problem with the international media.

\subsection{Public reaction to official response}

Public dissatisfaction with the official response is a common feature of unrest situations at volcanoes, especially when warnings are given about potential volcanic activity that does not eventuate. The bearers of bad news are commonly blamed or discredited by those who are affected by it.

The USGS received a large amount of criticism for releasing the "Volcanic Hazard Notice" at Long Valley in 1982. Local officials and the business community blamed them for the economic downturn that followed. Other criticism was directed at the way they had handled the release, especially the way locals found out about it via the media.

Barberi et al. [25] describes the response to the 1970 unrest at Campi Flegrei; "A violent controversy developed with deep 
involvement of the mass-media, which lasted for ten years. The arguments centred on the need and reasons for this evacuation and the alleged (or denied) interpretation of uplift and seismicity as precursors of an impending volcanic eruption."

\subsection{Emergency Preparedness}

Caldera unrest has commonly prompted authorities to initiate or enhance their emergency preparedness for potential volcanic activity. Such measures have generally been viewed as a positive outcome of the unrest period.

A range of emergency preparedness measures has resulted from the unrest at Long Valley. After the initial release of the "Volcanic Hazard Notice" the USGS in co-operation with the State of California has developed a response plan that defines response status (equivalent to New Zealand's Alert Levels) that can be used as a framework for civil authorities to gauge and co-ordinate their response to a developing crisis [34].

During the 1983-85 Rabaul unrest, national and provincial disaster committees were set up and undertook a range of preparedness activities, including evacuation planning and exercises [26]. Such activities clearly proved valuable 10 years later when volcanic activity commenced [35, 36, 37], but did result in significant expenditure.

A period of caldera unrest in New Zealand will result in the involvement of several agencies and organisations in planning and containment. The Institute of Geological \& Nuclear Sciences (GNS) would be responsible for monitoring the eruption precursors, setting the "Scientific Alert Level" and providing scientific information to the Ministry for Civil Defence and Emergency Management and other organisations. The Ministry for Civil Defence and Emergency Management, in turn would advise Govemment, regional and district councils. Other government organisations would be involved in specific responses including the Department of Internal Affairs, Department of Social Welfare, Ministry of Health and Ministry of Agriculture and Forestry.

Caldera unrest will stimulate the activation of agencies over a substantial geographical area and affect diverse communities. While each jurisdiction may have specific responsibility for problems in its area, the scale, distribution and duration of the problems discussed in this paper illustrates a need for an integrated response. Managing unrest would require multi-jurisdictional and multidisciplinary planning and the co-ordinated and integrated activity of several organisations, including scientific agencies [38]. Scientific agencies will have neither the resources nor the expertise to respond to all the possible requests that could emerge within this decision environment. Response agencies must acknowledge that they can receive data from scientific sources, but rendering it into a meaningful format, and one that is consistent with their decision needs, is a function of the quality of their prior dialogue with the scientific community and their own interpretative capability [39]. While response agencies may be familiar with the activities of the scientific community, this may not be at a level appropriate for emergency management. Hence there is a clear role for the scientific community in educating end-users about the information they provide and to discuss the implications of its implicit uncertainty for contingency planning, decision-making, and information dissemination.

\subsection{Summary}

Caldera unrest is one of the most difficult situations the volcanological and emergency management communities will have to deal with. If handled poorly, significant social, economic and political problems will occur, even without an eruption. In most cases unrest at Taupo will be caused by the broad-scale tectonic processes associated with extension of the central North Island and will be difficult to separate from a volcanic signature. However, any future unrest event may be the precursors to volcanic activity. Adverse response may take the form of the release of inappropriate advice, media speculation, unwarranted emergency declarations and premature cessation of economic activity and community services. A non-volcanic-crisis time provides the best opportunity to develop an understanding of the caldera unrest phenomena, and the best time to establish educational programmes, funding systems for enhanced emergency response and volcano surveillance and to develop co-ordinated contingency plans.

\section{ACKNOWLEDGEMENTS}

This study was funded by a contract from the New Zealand Foundation for Research Science and Technology. The manuscript benefited from constructive review by Vern Manville and Peter Otway.

\section{REFERENCES}

1. Newhall, C. G., and Dzurisin, D. (1988), "Historical unrest at large calderas of the world". USGS Bulletin $1855,1108 \mathrm{p}$.

2. Simkin, T., and Siebert L. (2000), "Earth's volcanoes and eruptions: an overview". In: H. Siggurdson (Ed.), Encyclopaedia of Volcanoes, Academic Press, New York, 249-261.

3. Johnston, D.M., Houghton, B.F., Neall, V.E., Ronan, K.R., and Paton, D. (2000), "Impacts of the 1945 and 1995-1996 Ruapehu eruptions, New Zealand: an example of increasing societal vulnerability". Geological Society of America Bulletin, 112: 720-726.

4. Crisp, J. (1984), "Rates of magma emplacement and volcanic output". Journal of Volcanology and Geothermal Research, 20:177-211.

5. Wilson, C.J.N. (1993), "Stratigraphy, chronolgy, styles and dynamics of late Quaternary eruptions from Taupo volcano, New Zealand". Philosophical Transactions of the Geological Society of London A343: 205-306.

6. Wilson, C.J.N. (2001), "The 26.5 ka Oruanui eruption, New Zealand: an introduction and overview". Journal of Volcanology and Geothermal Research 112: 133174.

7. Wilson, C.J.N., and Walker, G.P.L. (1985), "The Taupo eruption, New Zealand". I. General aspects. Philosophical Transactions of the Geological Society of London A314, 199-228. 
8. Villamor, P., and Berryman, K. (2001), "A late Quaternary extension rate in the Taupo Volcanic Zone, New Zealand, derived from fault slip data". New Zealand Journal of Geology and Geophysics 44: 243269.

9. Eiby, G.A. (1968), "An annotated list of New Zealand earthquakes 1460-1965". New Zealand Journal of Geology and Geophysics 11: 630-647.

10. Hill, H. (1911), "Napier to Runanga and the Taupo Plateau". Transactions of the New Zealand Institute 43: 288-296.

11. Grindley, G.W., and Hull, A.G. (1986), "Historical Taupo earthquakes and deformation". Royal Society of New Zealand Bulletin 24: 174-186.

12. Lowry, M.A., Ede, S.C., and Harris, J.S. (1989), "Assessment of seismic intensities resulting from the 1987 Edgecumbe earthquake, New Zealand, and implications for modernising the intensity scale". New Zealand Journal of Geology and Geophysics 21: 145 153.

13. Morgan, P.G. (1923), "Taupo Earthquakes". New Zealand Geological Survey 17th Annual Report p. 10-11.

14. Dowrick, D.J, and Rhoades, D.A. (1998), "Magnitudes of New Zealand earthquakes, 1901-1993. Bulletin New Zealand National Society for Earthquake Engineering 31(4): 260-280.

15. Grange, L.I. (1932), "The Taupo earthquakes, 1922. Rents and faults formed during the earthquake of 1922 in the Taupo District". New Zealand Journal of Science and Technology 14: 139-141.

16. Otway, P.M., Blick, G.H., and Scott., B.J. (2002), "Vertical deformation at Lake Taupo, New Zealand, from lake levelling surveys, 1979-99". New Zealand Journal of Geology and Geophysics 45: 119-30.

17. Sherburn S. (1992), "Seismicity of the Lake Taupo region, New Zealand, 1985-90". New Zealand Journal of Geology and Geophysics 35: 331-335.

18. Otway, P.M. and Sherbum, S. (1994), "Vertical deformation and shallow seismicity around Lake Taupo, New Zealand, 1985-90". New Zealand Journal of Geology and Geophysics 37: 195-200.

19. Otway P.M. (1986), "Vertical deformation associated with the Taupo earthquake swarm, June 1983". Royal Society of New Zealand Bulletin 24: 187-200.

20. Darby, D.J., and Williams, R.O. (1991), "A new geodetic estimate of deformation in the Central Volcanic Region of North Island, New Zealand". New Zealand Journal of Geology and Geophysics 34: 127136.

21. Kuester, I., and Forsyth, S. (1985), "Rabaul eruption risk; Population awareness and preparedness survey". Disaster 9(3): 179-182.

22. Bernknopf, R.L., Brookshire, D.S., and Thayer, M.A.
(1990), "Earthquake and volcano hazard notices: an economic evaluation of changes in risk perception". Journal of Environmental Economics and Management 18: $35-49$.

23. Latter, J. H., and Balsillie, F.H. (1985), "Shallow seismicity of the Taupo Volcanic Zone, Mt Egmont area and Auckland Volcanic Zone". New Zealand Volcanological Record No. 13

24. Latter, J. (1987), Shallow seismicity of the Taupo "Volcanic Zone and Mt Taranaki area". New Zealand Volcanological Record No. 15.

25. Barberi, F., Corrado, G., Innocenti, F., and Luongo, G. (1984), "Phlegraean Fields 1982-1984: brief chronicle of a volcano emergency in a densely populated area". Bulletin Volcanologique 47: 176-185.

26. Lowenstein, P.L. (1988). "The Rabaul seismodeformation crisis of 1983-85: monitoring, emergency planning and interaction with authorities, the media and the public". Proceedings of the Kagoshima International Conference on Volcanoes, Kagoshima, Japan, 580-582.

27. Bowie, R., and Easton B. (eds.) (1987), Business Opinion in New Zealand: The NZIER Survey, Research Paper 36, NZIER, Wellington.

28. Blong, R.J. (1984), "Volcanic Hazards: A sourcebook on the effects of eruptions". Academic Press, Australia, $424 \mathrm{p}$.

29. Mader, G.G., and Blair, M.L. (1987), "Living With a Volcanic Threat: response to volcanic hazards, Long Valley, California. Portola Valley, California: William Sprangle", $105 \mathrm{p}$.

30. Cochrane, H (1995), "The economic impact of earthquake disasters", paper presented to Wellington After the Quake conference, EQC, Wellington.

31. De Bondt, W. and Thaler, R. (1985), "Does the stockmarket overreact?" Journal of Finance 40: 793 805 .

32. De Bondt, W. and Thaler, R. (1987), "Further evidence on investor overreaction and stockmarket sensitivity". Journal of Finance 42: 557-581.

33. The Economist (1996), "Time to wet investors' appetites", 24 February, p.92.

34. Hill, D.P., Johnston, M.J.S., Langbein, S.R., McNutt, S.R., Miller, C.D., Mortensen, C.E., Pitt, A.M., and Rojstaczer, S. (1991). "Response plans for volcanic hazards in the Long Valley Caldera and Mono Craters Area, California". USGS Open-File 91-270.

35. Finnimore, E.T., Low, B.S., Martin, R.J., Karam, P., Nairn, I.A., and Scott, B.J. (1995), "Contingency planning for and emergency management of the 1994 Rabaul volcanic eruption, Papua New Guinea: results of a fact-finding visit". Ministry of Civil Defence, Wellington, $39 \mathrm{p}$. 
36. Davies, H. (1995), "The 1994 eruption of Rabaul volcano - A case study in disaster management". University of Papua New Guinea.

37. Nairn, I.A., and Scott, B.J. (1995), "Scientific management of the 1994 Rabaul eruption: lessons for New Zealand". Institute of Geological \& Nuclear Sciences science report 95/26, $46 \mathrm{p}$.

38. Paton, D., Johnston, D., Houghton, B., and Smith, L. (1998), "Managing the effects of a volcanic eruption: Psychological perspectives on integrated emergency management". Journal of the American Society of Professional Emergency Planners 5: 59-69.

39. Paton, D., Johnston, D., Houghton, Flin, R., Ronan, K., and Scott, B. (1999). "Managing natural hazard consequences: planning for information management and decision making". Journal of the American Society of Professional Emergency Planners 6: 37-48.

40. Farrar, C.D., Sorey M.L., Evans, W.C., Howie, J.F. Kerr, B.D., Kennedy, B.M., King, C.-Y., and Southon,
J.R. (1995), "Forest-killing diffuse $\mathrm{CO}_{2}$ emission at Mammoth Mountain as a sign of magmatic unrest". Nature 376: 675-678.

41. Dzurisin, D., Christiansen, R.L., and Pierce, K.L. (1995), "Yellowstone: restless volcanic giant". Volcanic Hazards Facts Sheet - USGS Open-File Report 95-59.

42. Barberi, F., and Carapezza, M.L. (1996), "The problem of volcanic unrest: the Campi Flegrei case history". In: Scarpa, R., Tilling, R.I. (eds.), Monitoring and Mitigation of Volcanic Hazards. Springer-Verlag, p. 771-786.

43. McKee, C. O., Johnson, R.W., Lowenstein, P.L., Riley, S.J., Blong, R.J., de St. Ours, P., and Talai, B. (1985), "Rabaul caldera, Papua New Guinea: volcanic hazards, surveillance, and eruption contingency planning". Journal of Volcanology and Geothermal Research 23: 195-237. 